\title{
A Comparative Analysis of Motifs from Minoan and Hungarian Folk Art
}

\author{
Peter Z. Revesz ${ }^{1, a}$ \\ ${ }^{1}$ Department of Computer Science, University of Nebraska-Lincoln, Lincoln, NE, 68588, USA
}

\begin{abstract}
This paper presents a similarity measure for motives. The similarity measure is applied to several ceramic and metal artifacts that contain spiral motives. The similarity measure shows a particularly strong similarity between some Minoan and Hungarian ceramics.
\end{abstract}

\section{Introduction}

Discoveries in the past few years showed connections between the Minoans and Hungarians, including the following:

1. Cretan Script Family - The Cretan Script Family [11] includes both Minoan scripts, called the Cretan Hieroglyph [19, 20, 21] and Linear A [7, 8], as well as Old Hungarian [4, 5], which is also called rovásírás in Hungarian and also written sometimes as Rovas in English language publications.

2. Ugric branch of the Finno-Ugric family of languages - The translation of about thirty Minoan texts shows that Minoan is closely related to the Ugric branch of the Finno-Ugric languages [12, 13, 14, 15] and could be classified to belong in that group. The corpus of Cretan Hieroglyph texts includes the Phaistos Disk [1], the Arkalochori Axe and the Malia Altar Stone inscriptions [14], which is item number 328 in the Corpus Hieroglyphicarum Inscriptionum Cretae (CHIC) [8].

3. Genetic Connections - Archaeogenetics identified about ten percent of Minoans as belonging to mitochondrial DNA haplogroup I5a [10]. This rare haplogroup also occurs in the proto-Ugric Mezhovskaya culture from about 1598-1398 BCE, in Vodokhranilische, Kazakhstan from about 14001000 BCE, and in Hungarians from about 975-1000, that is, after the Hungarian conquest period in 895 .

The above connections naturally lead to the question of whether some connections could be found also between Minoan and Hungarian Folk Art motifs. This paper investigates the similarities between the two sets of motifs.

This rest of this paper is organized as follows.
Section 2 describes some similarity features for motifs that involve spirals. Section 3 defines a motif similarity measure and gives some examples of its application. Finally Section 4 gives some conclusions and directions for future work.

\section{Features for spiral motifs}

A similarity measure for ceramic motifs could be considered as a modification of the similarity measure for pairs of script symbols [11]. We start by listing some features that can be evaluated of being present or absent in a ceramic motif when both motives contain spirals.

Feature 1. In both motifs the spirals are simple.

Feature 2. In both motifs the spirals are arranged in a fan-shape or in both motives the spirals fill in the space.

Feature 3. The motifs have the same number of spirals originating from the same point.

Feature 4. In both motifs, the spirals are decorated with small circles, which we call bubbles.

As an example considering Feature 1, the spirals on the Minoan jar shown in Fig. 1 are non-simple because they are double twisted spirals. The spirals on Figs. 2-4 are simple. As an example considering Feature 2, the spirals in Fig. 1 and Fig. 2 fill in the entire space, while the spirals Fig. 3 and Fig. 4 are arranged in fan shape stemming from a single point. As an example considering Feature 4, the spirals in Fig. 3 show bubbles.

While other features of spirals could be considered, the above list of features enables us to give some meaningful comparisons among several objects with spiral motives as shown in Section 3.

\footnotetext{
${ }^{a}$ Corresponding author: revesz@,cse.unl.edu
} 


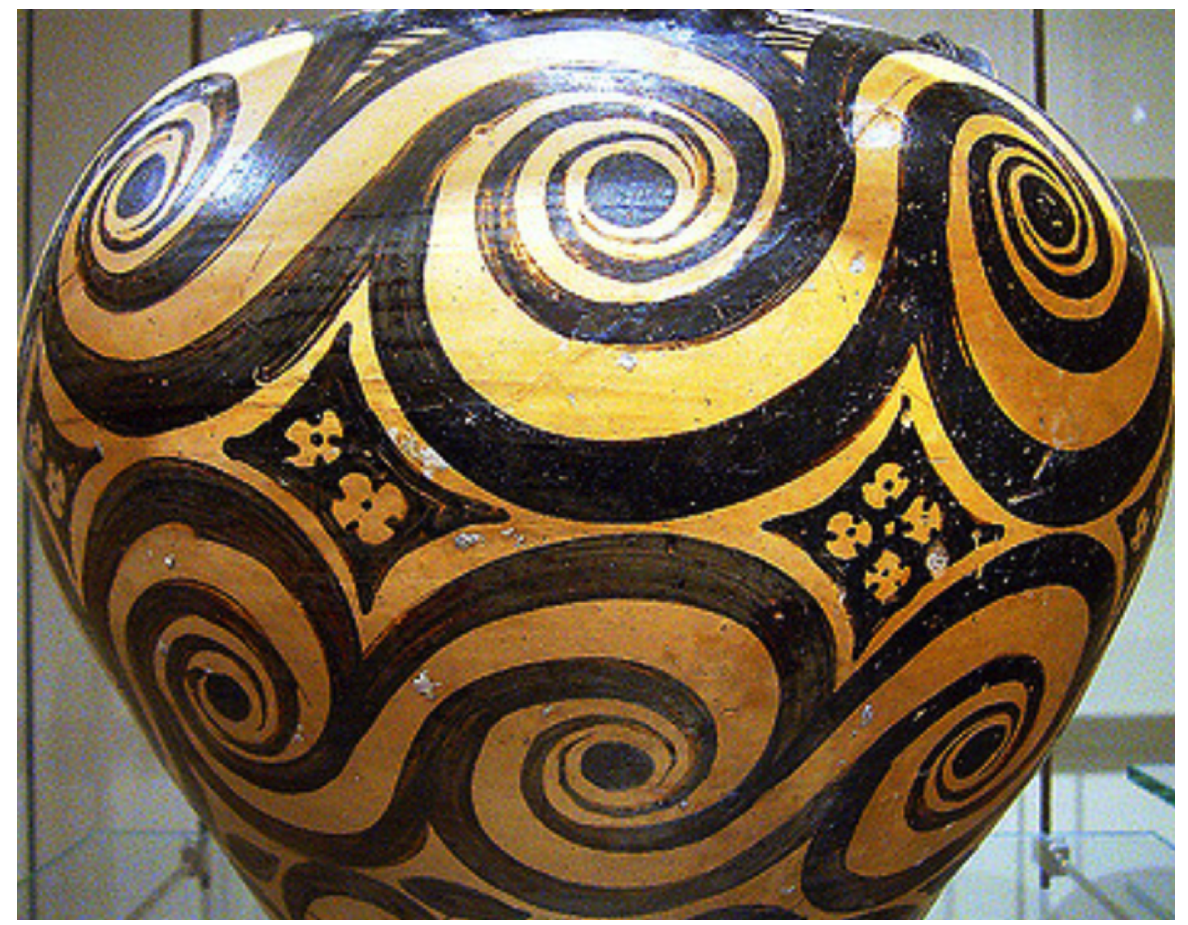

Fig. 1. Details of a Minoan jar with double twisted spiral motives (now in Metropolitan Museum of Art, New York).

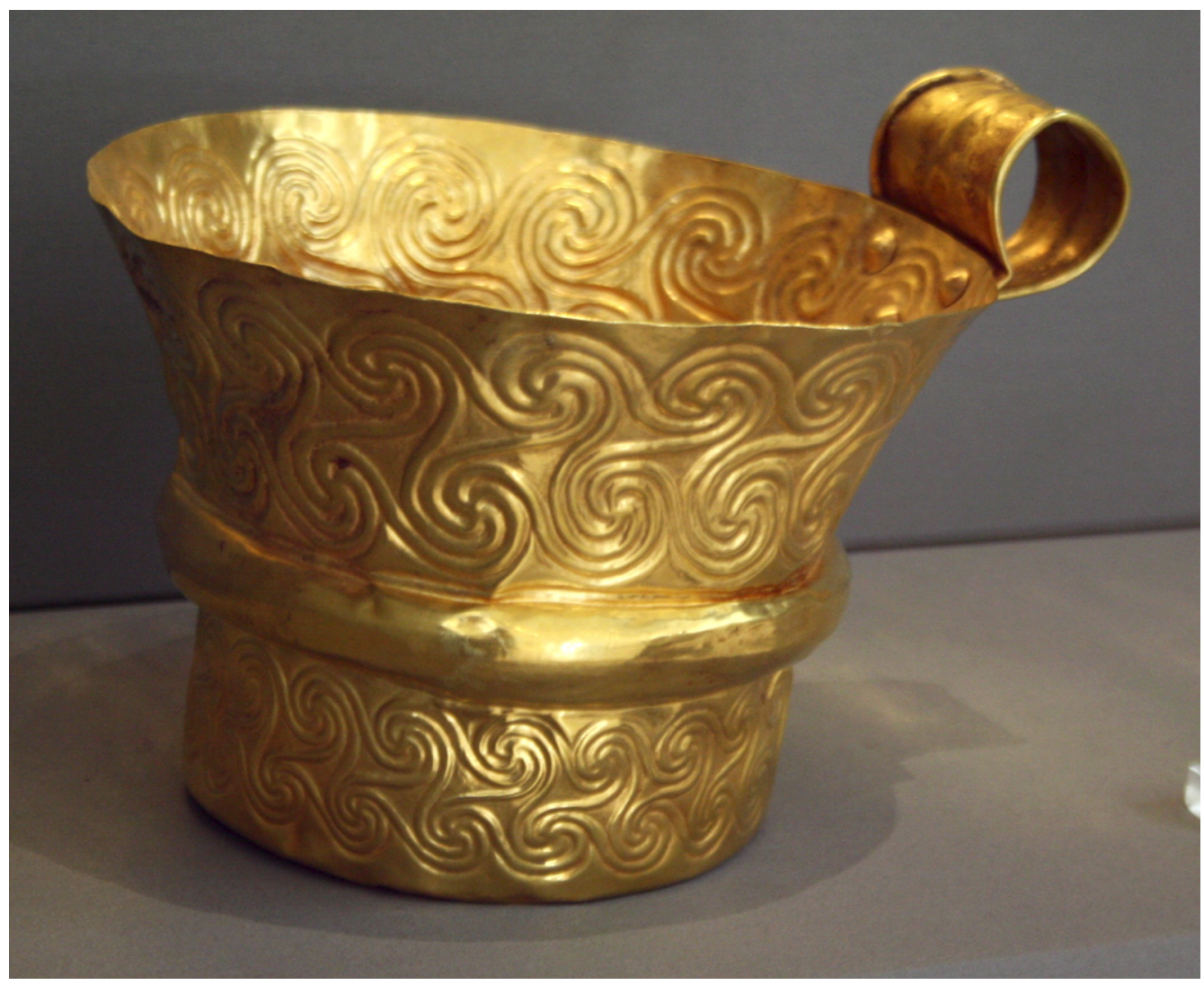

Fig. 2. Mycenaean gold cup. [Wikipedia: "Triskele" entry.] 


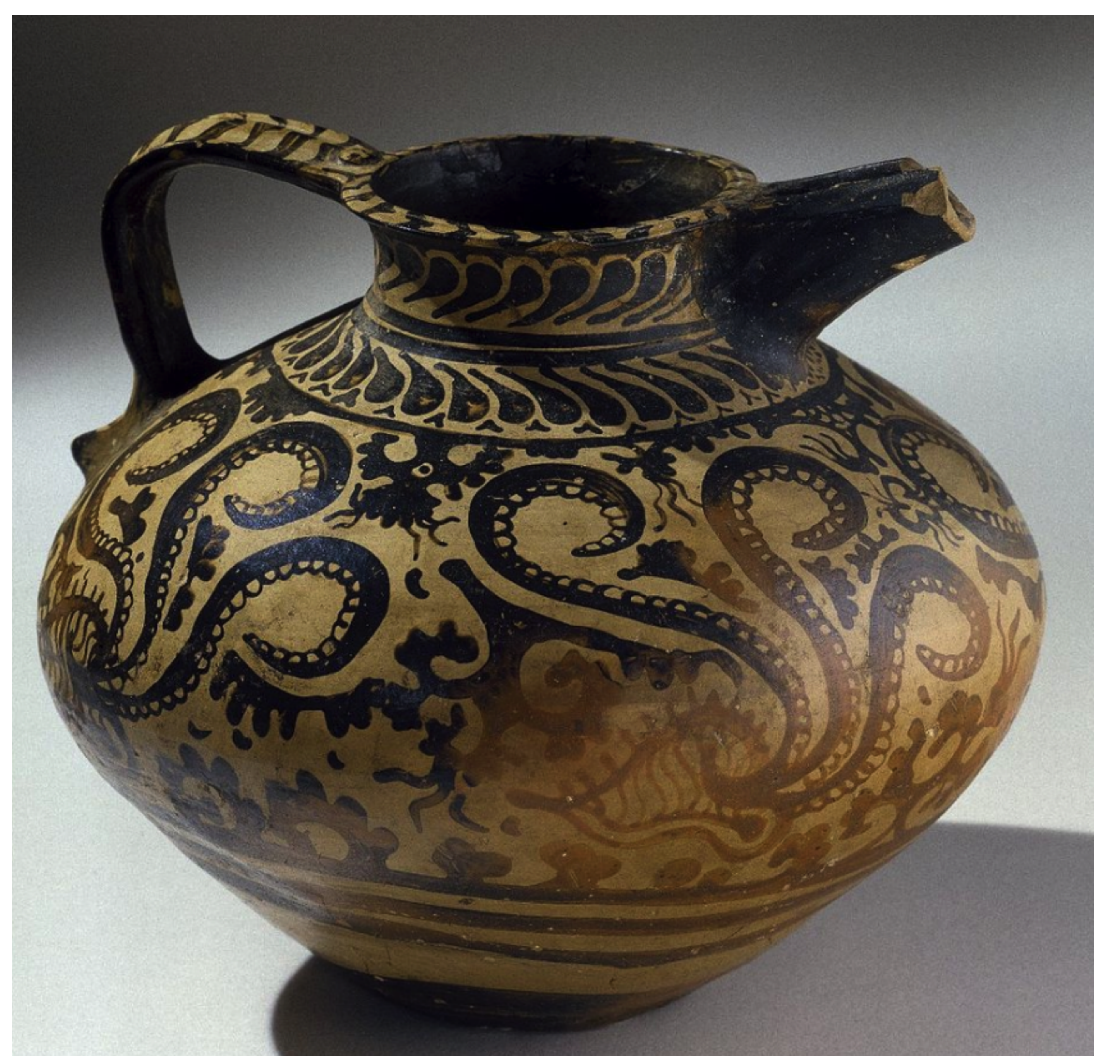

Fig. 3. A Minoan jug (ca. 1575-1500 BCE, now in the Brooklyn Museum).

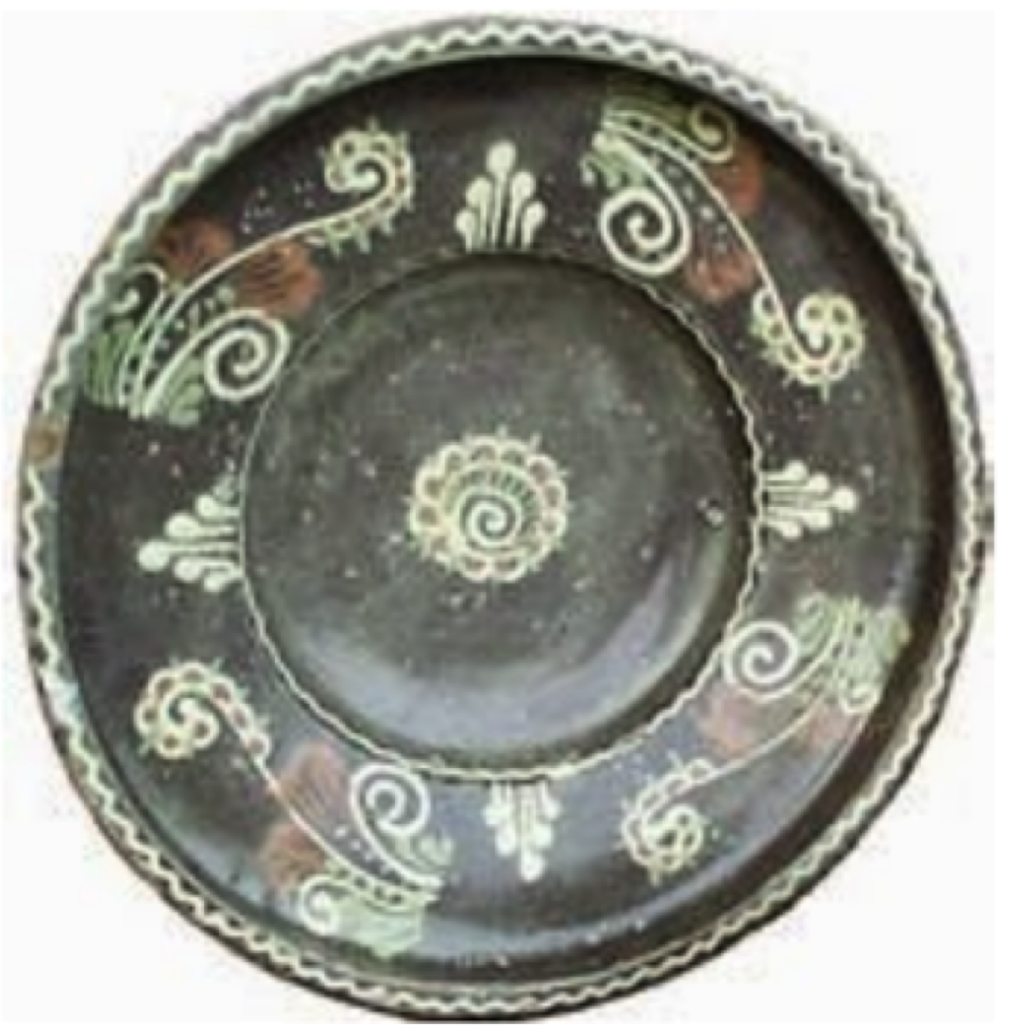

Fig. 4. Dish from Magyarszombatfa, Hungary, c. 1950 (Varga [17]). 


\section{A measure for motif similarity}

Based on the features listed in Section 2, we can define a motif similarity measure as follows:

Definition. The similarity of two motives is the number of common features (Features 1-4 above) that they contain.

For example, similarity between the Minoan jar in Fig. 1 and the Mycenaean gold cup in Fig. 2 is the following:

$$
\operatorname{Sim}(1,2)=2
$$

In this case, the spirals in Fig 1 are non-simple, while in Fig. 2 they are simple. The spirals in both figures fill in the entire space rather than being arranged in a fan shape. Feature 3 does not hold because the spirals do nto stem form a single point. Finally, neither spiral motif contains bubbles.

As another example, the similarity between the motifs of the Minoan jug in Fig. 3 and the Hungarian dish in Fig. 4 is the following:

$$
\operatorname{Sim}(3,4)=4
$$

Note that both Fig. 3 and Fig. 4 contain spirals arranged in a fan shape and triplets of spirals have a common origin in both. In addition, the spirals in both Fig. 3 and Fig. 4 contain bubbles.

It can be also checked that $\operatorname{Sim}(1,4)=0$, meaning that there is little similarity between the Mycenaean gold cup and the Hungarian dish.

\section{Conclusions and future work}

As the second example in Section 2 shows, there are some remarkable similarities between Minoan and Hungarian folk art motifs involving spirals. Spirals of various sorts are depicted even in early Neolithic art and continued to play a fascinating role in the history of art in many cultures. Therefore, it made sense to start our investigation with spiral motifs or patterns. In the future, we plan to extend our investigation to other commonly found motifs or patterns that involve animals and celestial objects such as the sun, the moon and the stars.

\section{References}

1. W. Achterberg, J. Best, K. Enzler, L. Rietveld, and F. Woudhuizen, The Phaistos Disc: A Luwian Letter to Nestor, Publications of the Henri Frankfort Foundation 13 (Amsterdam, Dutch Archaeological and Historical Society, 2004)

2. L. Benkő, Az Árpád-kor magyar nyelvü szövegemlékei (Budapest, ELTE, Régi Magyar Irodalomtudományi Intézet 1980)
3. J. Chadwick, The Decipherment of Linear B, (Cambridge University Press, 1958)

4. S. Forrai, The Old Hungarian Writing from Ancient Times to the Present, (in Hungarian), (Antológia Kiadó, Budapest, Hungary 1994)

5. G. Hosszú, Heritage of Scribes: The Relation of Rovas Scripts to Eurasian Writing Systems, (Rovas Foundation Hungary, Budapest, Hungary 2013)

6. P.C. Kanellakis, G.M. Kuper, P.Z. Revesz, J. of Comp. and Sys. Sciences, 51, 1, 26-52 (1995)

7. J.-P. Olivier, Cretan writing in the second millennium B.C., World Archaeology. 17, 3, 377-389 (1986).

8. J.-P. Olivier, L. Godart and J.-C. Poursat, Corpus Hieroglyphicarum Inscriptionum Cretae Études Crétoises 31, (De Boccard, Paris 1996)

9. P.Z. Revesz, Introduction to Databases: From Biological to Spatio-Temporal, (Springer, New York, 2010)

10. P.Z. Revesz, A spatio-temporal analysis of mitochondrial DNA haplogroup I, Proc. 20th Int. Conf. on Circuits, Systems, Comm. and Computers -- MATEC Web of Conferences, 76, no. 04048, Oct. 2016.

11. P.Z. Revesz, Bioinformatics evolutionary tree algorithms reveal the history of the Cretan script family, Int. Journal of Applied Mathematics and Informatics, 10, 67-76, (2016)

12. P.Z. Revesz, A computer-aided translation of the Phaistos Disk, Int. Journal of Computers, 10, 94-100, (2016)

13. P.Z. Revesz, A computer-aided translation of the Cretan Hieroglyph script, Int. J. Signal Proc., 1, 127-133 (2016)

14. P.Z. Revesz, A translation of the Arkalochori Axe and the Malia Altar Stone, WSEAS Transactions on Information Science and Applications, 14(1), 124-133 (2017)

15. P.Z. Revesz, Establishing the West-Ugric language family with Minoan, Hattic and Hungarian by a decipherment of Linear A, WSEAS Transactions on Information Science and Applications, 14(1), 306-335 (2017)

16. M. Shortridge, T. Triplet, P.Z. Revesz, M. Griep, R. Powers, Comp. Bio. and Chem., 35, 1, 24-33, (2011)

17. G. Varga, Magyar Hieroglif Írás, Irástörténeti Kutatóintézet, 2017.

18. Wikipedia, "Carian alphabets," downloaded April 5, 2017. Available: https://en.wikipedia.org/wiki/Carian alphabets

19. F. Woudhuizen, The Earliest Cretan Scripts, (Innsbrucker Beiträge zur Kulturwissenschaft 2006)

20. J. G. Young, Minos 31-32 (1996-1997[1999]) 379-400.

21. P. Yule, Early Cretan Seals: A Study of Chronology, Marburger Studien zur Vor und Frühgeschichte 4 (Mainz 1981) 